NBER WORKING PAPER SERIES

\title{
HIGH SCHOOL GRADUATION IN THE CONTEXT OF CHANGING ELEMENTARY سIAND SECONDARY EDUCATION POLICY AND INCOME INEQUALITY: THE LAST HALF CENTURY
}

\author{
Nora E. Gordon \\ Working Paper 19049 \\ http://www.nber.org/papers/w19049 \\ NATIONAL BUREAU OF ECONOMIC RESEARCH \\ 1050 Massachusetts Avenue \\ Cambridge, MA 02138
}

May 2013

This paper was prepared for the Human Capital and History Conference, held in Cambridge in honor of Claudia Goldin on December 7 and 8, 2012. The author thanks the conference and editorial team of Leah Boustan, Carola Frydman and Bob Margo for their thoughtful suggestions and guidance. Thanks to Richard Murnane and Sarah Reber for helpful discussions, and to Elizabeth Cascio and Sarah Reber for education spending data. Maria Joy and Meredith Zackey provided excellent research assistance. I am indebted to Claudia Goldin for her sage and kind mentorship. She sparked my interest in the historical evolution of educational institutions and human capital, and innumerable other topics, economic and otherwise. The views expressed herein are those of the author and do not necessarily reflect the views of the National Bureau of Economic Research.

NBER working papers are circulated for discussion and comment purposes. They have not been peerreviewed or been subject to the review by the NBER Board of Directors that accompanies official NBER publications.

(C) 2013 by Nora E. Gordon. All rights reserved. Short sections of text, not to exceed two paragraphs, may be quoted without explicit permission provided that full credit, including $(\mathrm{C}$ notice, is given to the source. 
High School Graduation in the Context of Changing Elementary and Secondary Education Policy and Income Inequality: The Last Half Century

Nora E. Gordon

NBER Working Paper No. 19049

May 2013

JEL No. I2,I20,I24,I28

\begin{abstract}
Goldin and Katz (2008) document the key role that the educational attainment of native-born workers in the U.S. has played in determining changing returns to skill and income distribution in the twentieth century, emphasizing the need to understand the forces driving the supply of educated workers. This paper examines stagnation in high school graduation rates from about 1970 to 2000, alongside dramatic changes in elementary and secondary educational institutions and income inequality over those years. I review the policy history of major changes in educational institutions, including but not limited to the massive increase in school spending, and related literature. I then present descriptive analysis of the relationships between income inequality and both graduation and school spending from 1963 to 2007. Results suggest that inequality at the top of the income distribution, which was negatively correlated with the establishment of public secondary schooling earlier in the twentieth century, was positively correlated not only with education spending levels but also with aggregate high school graduation rates at the state level in this later period.
\end{abstract}

Nora E. Gordon

Georgetown Public Policy Institute

306 Old North

37 th and O Streets NW

Washington, DC 20057

and NBER

neg24@georgetown.edu 


\section{INTRODUCTION}

In The Race between Education and Technology (2008), Goldin and Katz comprehensively examine the forces behind changes in returns to skill in the U.S. over the twentieth century. Their title summarizes key forces influencing the supply of and demand for skilled labor. They write, "Our central conclusion is that when it comes to changes in the wage structure and returns to skill, supply changes have been critical, and changes in the educational attainment of the native-born have driven the supply side." This paper examines part of the puzzle remaining at their conclusion: why did high school graduation rates stop improving in the latter portion of the twentieth century? Labor economists study this pattern in the context of increasing returns to skill and demand for education; though returns to a high school diploma itself have diminished, it continues to serve as a gateway to college and its associated increasing labor market rewards. In this paper, I focus on the supply of education. I describe changes in elementary and secondary educational institutions over the time of stagnating graduation rates, and explore the extent to which increasing income inequality may have affected both educational inputs and outcomes. For an excellent comprehensive discussion of the many other factors affecting high school graduation, I refer the reader to Murnane (2013).

I first review major changes in education policy over the past half century, including a massive aggregate increase in school spending, the decline in the inequality of resources across local school districts, the civil rights focus on various groups of students historically less likely to graduate, and the rise of the General Equivalency Degree (GED) program. I then describe, at the state level, how income inequality relates to graduation rates and, separately, school spending. The direction of the correlation between inequality and spending on public programs is theoretically ambiguous, and empirical literature examining education spending has mixed findings: Goldin and Katz (2008) find that income inequality slowed the establishment of public high schools from 1910 to 1938, while Boustan et al. (2012) and Corcoran and Evans (2010) show that more recent 
increases in income inequality at the local level, from 1970 to 2000, increased locally-generated elementary and secondary school revenue. Of course, measures of inequality also directly reflect returns to education and could affect graduation rates by changing demand for schooling independent of school spending or quality.

Becker's model of human capital provides a useful starting point for considering potential determinants of high school graduation and educational attainment more generally. Individuals optimize their investments in human capital by considering the expected costs of acquiring it and the stream of returns they anticipate earning from it. School quality, as determined by inputs and technologies, can affect both costs and benefits. Much of the education literature implicitly assumes that improvements in school quality reduce psychic costs of human capital acquisition by making the school experience more enjoyable or effective, and thus considers graduation to be an indicator of school quality, holding the demand for skilled labor constant. ${ }^{1}$ If the skill level of the entire workforce is increasing-whether due to the increasing returns to skill we see over this period or improvements in school quality-excess supply of skilled labor could depress returns (as in Freeman, 1976) to the point that individuals anticipating this response would lower their investments in human capital. I confine my discussion to the potential impact of changes in the supply of education, rather than labor market-induced changes in its demand, though both forces are affected by inequality and both shape individual decisions about attainment. ${ }^{2}$

High school graduation rates are a relevant outcome for several reasons. As a measure of human capital, they have implications for productivity and economic growth. Research points to the importance of achievement levels in earlier grades in determining persistence in high school (see

\footnotetext{
${ }^{1}$ Intended improvements in schools could well make schooling more costly, however. Changes in educational production could improve achievement conditional on constant enrollment but discourage enrollment and ultimately attainment, potentially to the point that the net effect is negative: consider high school exit exams, longer school days and years, or longer commutes to non-neighborhood schools due to desegregation or choice policies.

${ }^{2}$ For the evolving return to high school graduation and postsecondary education over this period, see Autor, Katz, and Kearney (2008).
} 
Rumberger, 2011), so studies of high school graduation indirectly allow us to study the elusive education production function, at the elementary and early childhood levels as well as the secondary level. The extent to which educational inputs are associated with student outcomes has long been a popular question among researchers, the media, and policymakers, most prominently emerging with the Coleman Report in 1966 and defining an entire subfield of the literature. The central difficulty in this literature on education production functions-which I will not surmount in this paper-is identifying exogenous sources of variation in educational inputs. Depending on the choice and measurement of inputs (e.g., school spending, class size, teacher salary) and outcomes (levels or gaps, achievement or attainment, exceeding minimum proficiency levels or more finely detailed distributional measures), researchers debate the extent to which outcomes have improved, stagnated, or declined with increased inputs. Many conclude that money does not "matter" in the production of education (e.g., Hanushek, 1997), though this assessment of the literature is far from universal (e.g., Krueger, 1998).

One natural extension to this line of questioning is how what one does with the money (in the language of Goldin and Katz, productivity versus resources alone) matters. Here researchers have had more success in constructing methodologies to credibly identify causal impacts, though often in highly specific contexts not readily amenable to generalization. They also have more frequently estimated statistically significant positive relationships between specific inputs and student outcomes, perhaps most notably with Project STAR's random assignment of Tennessee students and teachers showing a positive impact of smaller class size on student achievement. A major recent emphasis in this literature is a focus on the impact of individual teachers characterized by their quality based on past "value added" to student achievement (e.g., Rockoff, 2004). New research on longer-term outcomes from the experimental student assignment embedded within the design of Project STAR shows that both class size (Chetty et al., 2011) and teacher quality (Chetty, Friedman and Rockoff, 2011) have positive impacts on adult outcomes 
including college attendance (data constraints prevent them from examining high school graduation directly). In part as a response to some of this research, major education policy initiatives at the state and federal levels currently focus much more on encouraging the use of particular "scientifically-based" inputs or practices rather than on increasing_or maintaining, in the current budgetary climate-levels of overall resources.

This paper focuses on one outcome, the high school graduation rate, so I emphasize at the outset that there are multiple ways an individual could change investments in human capital without changing one's status as a high school graduate or dropout: for example, dropouts or graduates can exert variable levels of effort and correspondingly acquire different skills and levels of proficiency, and graduates could attain more or less post-secondary schooling. High school graduation does in most cases serve as a gatekeeper to postsecondary education, however, so high school graduation trends do affect trends in postsecondary attainment (see Heckman and LaFontaine, 2010).

Figure 1 replicates Goldin and Katz's Figure 9.2, which shows high school graduation rates from 1890 to 2004 . These rates grew throughout the period until peaking at 77 percent in $1969 .{ }^{3}$ The period from 1910, when only 8 percent of students graduated from high school, through 1940, the first year in which the median student continued through graduation, is known as the "high school movement" during which public high schools were established in local school districts throughout the nation. In The Race between Education and Technology, Goldin and Katz analyze differences in geographic trends in these rates, establishing important roles both for factors which affected family demand for education (manufacturing job prospects related to the opportunity cost of education, and average income) and the likelihood that local school districts would reach consensus to provide a public high school education (income inequality, and the stability of a community, proxied for by the share of the population over age 64). Graduation rates continued to

${ }^{3}$ Goldin and Katz calculate these rates by dividing annual counts of graduates from education agencies by the age-appropriate (17 year old) population at the state level. 
increase through 1969 followed by what Goldin and Katz describe as subsequent "backsliding" and then plateau. Rates then declined in the 1990s. As Murnane (2013) discusses, the trend reversed with increases in graduation rates from 2000 to 2010, perhaps in part due to a decline in the attractiveness of the GED relative to high school graduation as it became more difficult to receive a GED. For the original analysis in this paper, I define graduation rates using data from educational agencies with counts of high school graduates as the numerator and counts of students enrolled in eighth grade five years earlier as the denominator, and exclude GED recipients from the defined group of high school graduates. ${ }^{4}$ This measure shows that 76.5 percent of eighth graders nationwide persisted to graduate from high school in 1963. This increased to a high of 81.7 percent by 1969 , and dipped below the 1963 level, to a low of 76.1 percent, by 1979. Increases beginning in 2000 brought the national rate up to 78.7 percent, similar to the 1991 level.

Goldin and Katz ask about the extensive supply of secondary education in the first half of the twentieth century - why did some places establish high schools sooner than others? An analogous question for more recent decades is why some places spend more on public education. Might the same forces underlying the initial establishment of public high schools, most notably income inequality, continue to promote public support for education decades later? If so, if the spending improves school quality, might these forces correlate with higher graduation rates? While I am primarily interested in elementary and secondary school quality as a mechanism for these relationships, the descriptive nature of this investigation precludes any causal conclusions. This caveat is particularly important as inequality reflects changing returns to skill, which independently shape decisions about human capital investments.

In Section II, I summarize what we know about trends in high school graduation and the forces behind these trends, from analyses of both aggregate and micro-level data. I then describe

\footnotetext{
${ }^{4}$ As Heckman and LaFontaine note, this may be impossible for some observations in which states include GED recipients in the administrative counts of high school graduates reported to the National Center of Education Statistics (NCES) annually; they give New Jersey as one such example.
} 
major changes in American elementary and secondary education over the past half-century and how they might be expected to affect high school dropout in Section III. Section IV presents a descriptive analysis of the relationships among inequality, school spending, and high school graduation rates using state-level data from 1963 to 2007. Section V concludes by discussing other potential explanations for observed graduation patterns and future policy directions for improving educational attainment.

\section{Trends in High School Graduation and What (LitTLE) We Know ABout What Shapes Them}

\section{A. Literature on Aggregate Trends in High School Graduation}

Heckman and LaFontaine (2010) and Murnane (2013) present comprehensive reviews of the literature describing high school graduation. They note that much of the literature focuses on levels and gaps at a point in time, rather than on demonstrating historical trends, and emphasize the widely disparate levels reported across studies for ostensibly the same groups at the same points in time due to different approaches to measuring the graduation rate. These differences matter for first-order questions about the nature of trends in aggregate levels and gaps across groups, as well as in calculating estimates of returns to education and trends in inequality over time. One central difference across measures used by researchers is whether they are derived from measures of educational attainment in the adult population, backing out graduation cohorts from respondents' ages, or are based on counts of high school graduates produced by education agencies, relative to estimates of a cohort's size (measures used for reporting to state and federal government fall into the latter category). Within each of these approaches, there are a number of variations based on data sources. ${ }^{5}$ Depending on the time period of interest and desired level of geographic and demographic aggregation, researchers often do not have a choice among measures.

\footnotetext{
${ }^{5}$ In particular, there is much discussion about which grade to use as a proxy for cohort size when normalizing a school system's graduate counts by the relevant cohort's prior enrollment. Increased likelihood of retention
} 
Heckman and LaFontaine show that discrepancies across estimates from different data sources-including Census and CPS data used to measure attainment in the adult population, administrative data on graduates and completers (the latter group includes GED recipients) from educational agencies, and longitudinal research samples-can be resolved by ensuring that both the numerator and denominator of the high school graduation rate meet uniform criteria. ${ }^{6}$ They report trends quite similar to those reported by Goldin and Katz and shown in Figure 1 of this paper, with graduation rates peaking around 1970.

To get a sense of just how much measurement choices can yield differences in first-order characterizations of these patterns, consider that Mishel and Roy's (2006) analysis of CPS data from 1962 to 2004 describes "remarkable progress in raising... high school completion rates." This qualitatively different assessment hinges on the use of completion (defined to include GED recipiency) as an outcome rather than high school graduation. Their estimated trends differ qualitatively from those in Figure 1 throughout the time period and do not exhibit a peak around 1970. Murnane (2013) follows the general strategy of Heckman and LaFontaine while incorporating more recently released data from the American Community Surveys of 2002-2010; this exercise reveals an increase in graduation (not completion) rates from later, 2000 to 2010, while confirming the general aggregate trend identified by Heckman and LaFontaine (and, again, generally consistent with Figure 1) prior to 2000. Overall, the analyses of graduation rates by Goldin and Katz, Heckman and LaFontaine, Murnane, and myself identify very similar trends. Within the aggregate graduation trend, Figure 2 reveals significant regional variation. The most immediately visible regional deviation from the national average is in the South, which started out behind in the 1960s with a 63 percent graduation rate compared to rates exceeding 80 percent

in grade nine can make the choice of grade nine versus eight or ten, or an average of multiple grades, nontrivial. See Swanson (2004).

${ }^{6}$ They focus on a sample that includes all students attending school in the US and only those studentsincluding those later incarcerated, and excluding immigrants who arrive in the US after completing their schooling, for example-and use administrative data on GED test-takers to exclude GED recipients from high school graduate counts derived from Census data. 
in the three other Census regions. This is unsurprising given the inferior educational opportunities available to blacks in the South, but, as Goldin and Katz and others note, was also due to poor outcomes for Southern whites. Though the South did subsequently experience brief periods of decline, the general trend over the decades was much more positive than in the other regions, with the graduation rate reaching 75 percent by 2007. Trends for the Northeast and Midwest were relatively similar to one another, starting out high (at 83 and 82 percent respectively in 1963) and peaking soon after before prolonged decline. By 2007, graduation rates had not yet returned to their peaks, with rates of 85 percent in the Northeast and 84 percent in the Midwest. The West, which started out with the highest graduation rates of any region at 85 percent in 1963, experienced the greatest decline over the period, and was the sole region ending the period far below its initial level, with only 75 percent of students graduating in 2007. Differential demographic trends are one obvious potential explanation for such regional differences; consider, for example, increased immigration and enrollment of language minority students in the West. How demographics affect graduation rates could also be changing over time differentially across regions; for example, the remarkable improvement in attainment in the South is likely related to the impact of desegregation. Regional differences could also be attributable to different trends in the level and distribution of school resources.

\section{B. Literature on Factors Influencing Graduation Rates}

As noted above, little of the literature attempting to disentangle the determinants of high school graduation (often framed as understanding dropout, rather than graduation) tries to do so by understanding long-term historical trends. Goldin and Katz's analysis of the high school movement points to the importance of both supply and demand factors for early adoption of public secondary schooling and graduation rates (see their Table 6.1). The mechanism for generating variance in high school graduation rates in these early decades is a first-order one: one is more likely to graduate from high school if one has access to a free public secondary school. 
One related contemporary literature asks what forces shape gaps in graduation rates across demographic groups (but still at aggregate levels) over time. Although recent work points to the growing importance of socioeconomic gaps in educational outcomes (see Reardon, 2011), racial gaps have received more attention in the accumulated literature to date. These attempts have generally concluded that trends in black graduation rates drive the observed trends in the gap, and that much of the timing of this stagnation and reversal is unexplained (see Neal, 2006; Ferguson, 2008), though some of it can be attributed to policy changes (see Vigdor and Ludwig, 2008, on the role of school segregation, and Evans, Garthwaite and Moore, 2012, on the role of crack cocaine). In this paper, I focus on aggregate trends rather than trends within or gaps across groups to study a longer historical period, including earlier years in which administrative graduation data disaggregated by demographic groups are not available.

Another literature investigates determinants of graduation outcomes at the individual level. Such research is necessarily limited to years in which sufficiently rich micro-level data are available, and cannot provide annual estimates like the literature on gaps or aggregates. This cost comes alongside the considerable benefit of richer data. Recent work by Altonji and Mansfield (2011) analyzes two such databases, the National Education Longitudinal Study (NELS: 1988), which tracks the spring 1988 eighth-grade cohort slated for "on-time" high school graduation in 1992, and the Education Longitudinal Study (ELS: 2002), which tracks the spring 2002 tenth-grade cohort who would graduate on time in 2004 . They assess the correlations between students' home, school and community characteristics and their likelihood of graduating from high school. They emphasize that they cannot estimate the causal impact of these factors, but rather are illuminating the extent to which school and community characteristics have explanatory power beyond the aggregation of individual characteristics. This distinction is crucial, particularly in the context of highly publicized research describing so-called "dropout factories"—-the public high schools with disproportionately high concentrations of poverty, concentrated in Northeastern cities and in the 
South—that Balfanz and Legters (2004) show disproportionately "produce" the nation's high school dropouts. If the school-level socioeconomic characteristics of these high schools exert a significant and negative independent force on graduation rates after controlling for the independent role of those same variables at the student level, policies to reduce the concentration of poverty in schools-for example, school desegregation by poverty, income, or other sufficiently highly correlated student characteristics—could improve graduation rates absent any reduction in child poverty rates. Alternately, if school-level demographics appear to operate primarily through the aggregation of individual-level characteristics, one would look to public policies aimed at poverty itself to improve educational attainment.

Altonji and Mansfield find a statistically and economically significant relationship between school and community characteristics ${ }^{7}$ and the likelihood that any given student will graduate from high school. ${ }^{8}$ They also examine the across-school variance in the composite quality measure for both these cohorts and the high school senior class of 1972, revealing significant increases in between-school variance from 1972 to 1993, and a slight increase from 1993 to 2005. This is consistent with the documented trend of increased residential segregation by income over that time period (Watson, 2009), given the dominance of residentially determined school attendance and the authors' use of peer socioeconomic characteristics as an input into their composite school quality measure. Altonji and Mansfield emphasize, however, that for both the NELS and ELS cohorts the relationship between school and community characteristics and individual graduation outcomes is much weaker than the relationship between individual students' characteristics and graduation outcomes. Among individual students' characteristics affecting within-school probabilities of

\footnotetext{
${ }^{7}$ These characteristics include both student characteristics aggregated up to the school level, and school characteristics such as teacher turnover and student-teacher ratios. They combine these characteristics into a single dimension of school quality, as determined by what predicts student outcomes, by which they rank schools.

${ }^{8}$ Specifically, they estimate that moving a given student from a high school at the $10^{\text {th }}$ percentile of the school quality composite index to the $90^{\text {th }}$ percentile is associated with being seven percentage points more likely to graduate from high school in the NELS: 88 cohort, for whom the average dropout rate was nine percent, and nine percentage points more likely in the ELS: 2002 cohort, for whom the average dropout rate was ten percent.
} 
graduation, the typical observable characteristics-family structure and various components of socio-economic status - matter, and unobservable characteristics explain even more of the variance. Their results therefore suggest that to the extent increased income inequality over time is driven by increases in poverty, it would be negatively correlated with graduation rates, but also that inequality itself is not the primary mechanism behind the individual outcomes for those students at the bottom of the income distribution.

\section{A BRiEF History of RECENT CHANGES IN U.S. EdUCATION POLICY AND TEACHER LABOR MARKETS}

Systems of public elementary and secondary education finance and governance in the U.S. today differ markedly from those in place in the decades when graduation rates were climbing. Some of the most prominent policy changes-for example, court-ordered desegregation, state-level school finance equalization reforms, and the federal requirement of a free and appropriate education for students with special needs-were designed with the intent of improving educational outcomes for specific groups; students in these groups were also those historically less likely to graduate from high school. To affect graduation rates, these policies would need to reach those targeted students and to engender effective changes in educational practice, neither of which are straightforward goals. Whatever funds "stick" to district budgets must be allocated across schools within districts (this is relevant even for districts with one high school, given the correlation between academic achievement prior to high school and persistence to graduation), and within schools, allocated to particular instructional settings and therefore not benefiting all students in the school uniformly. Unfortunately, we know relatively little about the distribution of instructional resources below the district level and how it may have changed over this time period.

Alongside federal, state, and local changes in elementary and secondary education policy over these years came significant changes in the teacher labor market and in the demographic composition of students. As attractive labor market options beyond teaching have expanded for 
college-educated women, these options have disproportionately drawn women from the upper part of the distributions of various measures of cognitive skill from the pool of potential teachers.

Changes in family structure have led to increasing numbers of students coming from single-parent homes, which is positively correlated with high school dropout (McLanahan and Sandefur, 1994). The time-series data alone, showing stagnating graduation rates alongside major education policy initiatives, thus do not necessarily imply that we are not better off with particular reforms than we would have been without them.

In the following subsections, I detail key changes in federal, state, and local revenues and programs. Many of these changes are captured by Figure 3, which shows the evolution of revenue and spending per pupil. For most of the United States' history, and in most states, the vast majority of school spending was funded through locally generated revenue streams. ${ }^{9}$ This reliance on local revenue was accompanied by a great deal of local control. Though states assume constitutional responsibility for education and have no obligation to allow local control, they historically have devolved much of education governance to local districts, while retaining control over decisions such as ages of mandatory attendance, minimum required days per school year, and requirements for teacher credentialing at the state level (Briffault, 2005). Over the same time period that graduation rates declined and stagnated, centralization increased in school finance, with increased roles for the federal and state governments.

Figure 3 and Table 1 also reveal the marked increase in school spending over the past halfcentury. The national average for current spending (excluding capital investments), discussed throughout in per pupil terms in 2011 dollars, rose from about $\$ 3,400$ to over $\$ 12,000$ from 1963 to 2007. This has not gone unnoticed: education policy discussions nearly always frame trends in

\footnotetext{
${ }^{9}$ Local revenue refers to that generated at the school district level. In the minority of states in which school districts are "dependent" on parent governments such as counties, cities, or other local governments, the taxes are levied and revenue collected by the parent government rather than by the school district itself; for both independent and dependent districts, "local" revenue is raised from the geographic area contiguous with the school district.
} 
achievement and attainment in the context of this dramatic increase. The rest of this section discusses major changes in federal, state and local policy, as well as changes in teacher labor markets.

\section{Changes in federal education policy}

The federal role in elementary and secondary school finance initially emerged in a significant way with the Elementary and Secondary Education Act (ESEA) of 1965. ESEA and its largest program, Title I, changed the nature of federal education policy in three key ways. First, it was a sizeable revenue increase for some districts. The federal government had provided funds to districts (via their state education agencies) earlier through a few categorical programs, with Aid to Federally Impacted Areas and the National Defense and Education Act as the largest funding streams, but these other sources together totaled only about 3 percent of what the average district spent. Southern districts, with their high poverty rates, benefited disproportionately from Title I, with the first Title I grants equal to about 15 percent of pre-existing spending levels in Southern districts. In Figure 3, we see the national data, with federal revenue overall accounting for 7.9 percent of spending in 1965 compared to 4.4 percent just the year before. While Title I significantly increased federal spending, however, it is important to remember that all federal revenue constitutes just under 10 percent of total school district revenues in the US today.

Second, the Title I program aims to provide compensatory education and is explicitly designed to be redistributive, with funding based primarily on child poverty counts in a district. Title I as a share of spending has therefore always varied by district. The extent to which Title I redistributed resources to less advantaged students remains an open question. It would first need to resist crowd-out of state and local revenues to supplement spending at the district level. Cascio, Gordon, and Reber (forthcoming) show that nearly half of Title I revenues did ultimately supplement local spending on average in the late 1960s, and significantly more so in districts experiencing larger shocks from Title I grants relative to their existing budgets. Gordon (2004) 
shows that this was unlikely by the mid-1990s. Conditional on "sticking" to school spending at the district level, Title I funds might not make their way to the most disadvantaged students within districts - who are disproportionately those on the margin of choosing to drop out of high school. Cascio, Gordon and Reber examine the South of the 1960s and find that Title I-induced net increases in district-level spending were associated with improvements in high school graduation rates for whites but not blacks. Qualitative data publicized by advocates from the NAACP Legal Defense Fund also suggests that local officials often found ways to use federal funds in unintended ways (Martin and McClure, 1969).

The regulatory framework meant to ensure that funds make their way to the most disadvantaged students has grown more legally complex and tightly enforced over time. However, Roza (2010) and Heuer and Stullich (2011) suggest that the (generally opaque to the researcher) ways in which districts allocate resources across their schools continue to offset the redistributive intent of the Title I program, violating the spirit of the law and its regulatory guidance. Further, the accounting systems of state and local education agencies make it difficult to capture resources in dollar units (as opposed to full-time equivalent staff, or FTEs) at the school level. Federal regulators thus allow districts to comply with Title I by smoothing FTEs rather than dollars across schools before layering on Title I funds, in what is known as the "comparability loophole."

Third, and perhaps most significantly, offering such sizeable grants allowed the federal government to require that school districts meet conditions of their choosing in order to receive the funds, providing a mechanism for the federal government to intervene in a policy sector in which it otherwise has no constitutional right to do so. This conditionality of funding was most relevant at the inception of Title I not in the context of ensuring that funds benefited disadvantaged students within a district (to which the federal government devoted little effort at the time) but rather in enforcing the desegregation requirements legislated in the Civil Rights Act of 1964, which withheld federal funds to discriminatory public agencies across policy functions (see Cascio et al., 2010). 
Most recently, the 2001 reauthorization of ESEA as the No Child Left Behind Act withholds Title I funds from states that fail to establish accountability systems meeting its requirements. ${ }^{10}$ This prompted resistance from states and districts that have come to rely on Title I funds, litigation, and ultimately a ruling from the U.S. Court of Appeals for the Sixth Circuit that NCLB provides conditional aid rather than an unfunded mandate and is therefore legal (Pontiac v. Spellings, 2009). Research suggests that the net impact of NCLB on achievement is neutral to positive, depending on the outcomes measured (Dee and Jacob, 2011). Overall, the use of conditions with federal funds has magnified their influence beyond that implied solely by the relatively small share of total revenue they constitute.

While some of the increase in federal funding over time has come through increases in allocations to the Title I budget, new federal programs have also contributed to the rise. Perhaps more notable than the funds provided by these programs is their categorical nature and the extent to which they have attempted to force local districts to channel resources to groups of (variably defined) disadvantaged students. The introduction of federal categorical programs was followed by increasing numbers of states relying more heavily on categorical funding streams in distributing their own revenue to school districts. If this relationship is casual, the impact of federal funds extends far beyond dollars appearing as federal revenue in district financial reporting. The federal categorical programs are notable for the various groups they aim to serve and to whom they provide legal recourse; the amount of funding provided through them, however, remains small compared to total education revenue.

The introduction of new programs, with the exception of ESEA, thus generally does not register as remarkable in the time series of federal revenue or current spending displayed in Figure 3. For ease of reference, the figure does not note all programs; close examination reveals noticeably

\footnotetext{
${ }^{10}$ More recently, the process by which the Department of Education grants waivers to states with limited ability to comply with NCLB could be viewed as a more ad hoc form of conditional grants, in which the conditions are less transparent and state education agencies tailor their applications to meet federal policy preferences through an iterative process.
} 
absent upticks for new programs, such as the Individuals with Disabilities Education Act of 1970, in 1972 for Title IX promoting gender equity, and in 1968 for the Bilingual Education Act (see Gordon, 2008 for more detailed discussion of these and other federal education programs). Some of the most significant federal interventions in elementary and secondary schooling in these decades comes through the federal judicial actions to desegregate schools (see Cascio, Gordon, Lewis and Reber, 2008 for further discussion); these mandates have been associated with increased likelihood of graduation for blacks (Guryan, 2004; Reber, 2010) but not with significant federal revenue to school districts.

Also not shown in the historical time series of Figure 3 is the most recent increase in federal education funds, much of which was due to the American Recovery and Reinvestment Act of 2009 (ARRA). Rather than solely expanding funding for existing programs, such as the traditional form of ESEA Title I, the ARRA funds were targeted to several new initiatives that differ qualitatively in their approach to the federal role in education. Two of the ones that are most significant, in both the magnitude of funds allocated and in their departure from the traditional structure of federal aid, are the School Improvement Grants and Race to the Top programs.

School Improvement Grants (SIGs) are similar to the federal Comprehensive School Reform (CSR) grants program of the 1990s but on a much larger scale. Both SIGs and CSR often channel funds through school districts to private contractors for tasks-related to school management, curriculum, and instruction—typically carried out by public school and district employees. While for many years discussions of privatization in schooling centered around the theoretically interesting potential for vouchers, the advent of SIGs points to an increased role for private vendors operating within what are still public schools. Burch (2006) describes how private suppliers increased following accountability reforms prior to SIGs; Forbes and Gordon (2012) show how competitive markets for private suppliers of intermediate goods in education markets may not lead to improvements in school quality. 
The Race to the Top (RttT) program innovates by bringing a tournament model to federal education funds, while retaining the traditional flow of revenues from the federal government to state education agencies (or, in the most recent round, directly to local education agencies). While ESEA at its inception in 1965 offered the carrot of Title I funds to all agencies meeting its conditions (most bindingly, its desegregation requirements), RttT is explicitly a competition, laying out a menu of how agencies can accumulate points for their proposals in exchange for implementing policies in advance or including specific practices in their grant proposals. This appears to have been quite cost effective from the federal perspective: the prospect of "winning" the race-as much as $\$ 700$ million for large states like Florida and New York-prompted many states to change politically entrenched policies, though fewer than half the states have successfully won any of the three (to date) rounds of the race and ultimately received a grant.

Overall, the federal level has emerged as a policy force since the 1960s, more than doubling its share of education revenue and shaping local policies via civil rights protections and conditions of aid. Despite this increase, the magnitude of federal funds has remained low enough that they do not explain the massive growth in school spending witnessed over the full span of this period. For this, I turn next to state policies.

\section{Changes in state education policy}

Figure 3 shows a climb in the share of total revenue coming from the states beginning around 1970. In many cases, these increases were prompted as part of school finance reforms that increased the progressivity of state formula aid (not visible within this figure), and were often in response to state level judicial mandates. These court rulings have overturned the constitutionality of school finance systems in the majority of states to date, often multiple times within a state; see Corcoran and Evans (2008) for more details and a listing of cases. The first such ruling, with some of the most dramatic consequences, came in 1971's Serrano v. Priest decision by the California 
Supreme Court. This is marked on Figure 3 as "Serrano I" to distinguish it from subsequent rulings in 1976 and 1977, known as Serrano II and III respectively, which sparked more dramatic reforms.

While the reforms to school finance following such rulings have differed substantively across states and over time (Hoxby, 2001), Murray, Evans, and Schwab (1998) show that on average, these rulings have been associated with increased spending per pupil and increased progressivity of spending within states. ${ }^{11}$ Card and Payne (2002) show that court-ordered school finance equalization (SFE) reforms increased the progressivity of spending within states and narrowed the gap in SAT scores by family income in affected states. SFEs could increase the observed progressivity of spending (where the district is the smallest unit observed) without necessarily affecting graduation rates if funds are disproportionately directed to higher achieving students, such as future SAT takers, rather than students on the margin of dropping out.

States have exerted their influence over local districts historically through compulsory attendance laws (albeit with generally weak enforcement) and teacher credentialing requirements. More recently, states adopted curricular standards and subsequently imposed accountability systems with assessments at least nominally aligned to their standards, in many cases before they were required to do so by No Child Left Behind (which was modeled on existing state programs) if they wanted to continue to collect Title I funds. Murnane (2013) posits that the standards and accountability movements, broadly speaking, may have contributed to the stagnation of high school graduation rates near the end of the twentieth century by increasing the nonmonetary cost of school attendance. Finally, as new dimensions emerge in education policy, state regulations do so as well. For example, states are increasingly involved in homeschooling and online learning. Local policies and practices

Traditionally, the local school district was the dominant political jurisdiction in determining total revenue and policy choices. The most readily identifiable changes in education policy in recent

${ }^{11}$ California is a notable exception. See Fischel (1989) on the relationship between its school finance reform and the subsequent passage of Proposition 13, limiting growth in property tax revenues. 
decades have been major state and federal initiatives, in part because of their inherent scale. This is not to say that school districts have not innovated; some large school districts have done so in highly visible ways, such as using value-added components in teacher assessments and compensation in Denver and Washington, D.C. But local districts ultimately implement instructional programs and the effects of "big" federal and state programs depend critically on how school districts crowd out intergovernmental grants and use any net additional funds or work towards newly defined goals through changes in practice.

The extent to which school districts have crowded out state and federal intergovernmental grants by reducing local revenues appears to vary considerably, as discussed in the federal and state policy sections above. And while researchers have long acknowledged the importance of local implementation (McLaughlin, 1976), we continue to know remarkably little about how most districts allocate resources across schools and how schools allocate resources across students (Roza, 2010).

A series of studies by Marguerite Roza and colleagues (see Roza, 2010 for a summary) is particularly illuminating of crowd out within school district budgets, when grants from state or federal governments nominally are allocated to typically disadvantaged schools meeting the relevant qualifications for different categorical programs, but unrestricted funds (e.g. from local revenue) are disproportionately allocated to schools receiving less aid from higher levels of government via categorical programs.

While it would be fascinating to look at the distribution of within-district allocations for a large sample of school districts over time, this type of large sample school-level analysis is impossible based on existing data sources. Guin et al. (2007) use administrative data from the Texas Education Agency from 1994 to 2003-unusual in detailing district-level allocations to schools in dollars rather than full-time equivalent staff-and find that the variance in spending per pupil found within districts exceeds that measured across districts in Texas. School finance reform 
in Texas led to a system with a high degree of redistribution across districts, so other states likely have greater cross-district variance. There is no reason to expect, however, that extensive withindistrict variance in resources at the school level is specific to Texas or to this time period. ${ }^{12}$

Figure 4 shows how dollars from different funding streams are allocated across one anonymous Texas district. Schools with low poverty rates get more state and local revenue than poor schools, which get a disproportionate share of their resources via federal funds. This violates the intention of Title I-to supplement resources for poor students, layering the federal funds on top of state and local funds already equalized across schools at the district level. Because of the comparability loophole discussed previously, however, it is technically legal. It is also quite difficult for districts to avoid given standard human resource policies. Districts typically open up new teaching positions first to teachers already working within the district. Teachers new to the district often enter through low SES schools, then transfer to higher SES schools as positions open. This leaves high poverty schools with a disproportionately inexperienced-and therefore cheapworkforce. Were districts to equalize spending in dollars, rather than FTEs, across schools, class sizes in low poverty schools would so far exceed those in high poverty schools as to be politically infeasible.

I can only speculate on trends in within-district inequality of educational resources-even in dollars, much less in quality-over time given the scarcity of data at the school level. It is possible that policy changes in recent decades have helped lower performing schools, as the stakes and transparency of accountability systems might have pushed districts toward targeting low-achieving students and the schools in which they are disproportionately clustered.

\footnotetext{
12 The information systems are simply not in place, even administratively, to conduct such analyses for earlier time periods and in many other states. In the majority of cases, such analysis would require access to multiple administrative data systems at the district rather than state level (e.g., one database to determine individual teachers' salaries and another for their school placements).
} 


\section{Changes in the labor market for teachers}

The most recent direction for researchers studying education production functions is trying to identify teacher quality as an output-based measure. The main conclusion of the literature to date is that there is high variance in teacher quality, most of which is unexplained by observable characteristics, and therefore unfortunately does not yield clear policy implications for teacher selection or training. This literature prompts the question whether any stagnation in educational outcomes, such as graduation rates, might be attributed in part to stagnation or decline in teacher quality. A related literature examines the role of women's labor market conditions and the labor supply of teachers, and concludes that expansions of labor market opportunities for collegeeducated women in recent decades have resulted in a teaching workforce that looks considerably less competitive than it used to (see Bacolod, 2007; Corcoran, Evans, and Schwab, 2004; and Hoxby, 2004).

\section{Changes in the GED program}

The General Equivalency Degree program awards a credential of secondary education based on test performance to those who have not completed high school and is perceived by some students as a substitute for a traditional high school diploma. In his review of the high school dropout literature, Murnane (2013) speculates that the increased difficulty of the GED exam beginning in 2002 is a likely contributor to the increase in high school graduation from 2000 to 2010. This is consistent with evidence from Heckman et al. (2012), who analyze several natural experiments in changes in GED requirements.

\section{INCOME INEQUALITY AND HIGH SCHOOL GRADUATION}

Duncan and Murnane (2011) set out a comprehensive model for how income inequality can affect educational outcomes, including its impact on home, community, and school environments. This model suggests that inequality could affect outcomes such as graduation rates, even 
conditional on the educational setting experienced by students, for example, by depressing student expectations. Overall, the economics literature has contributed mainly to the mechanism in this larger model by which demographic heterogeneity, including income inequality, affects demand for public spending; my analysis here continues in this tradition. Determining the direction of this effect is neither theoretically nor empirically straightforward.

The main theoretical ambiguity comes from two models with opposite predictions. Empirical work by Goldin and Katz (1997, 2008), Poterba (1997), Alesina, Baqir, and Easterly (1999), and Luttmer (2001), among others, supports a model in which fractionalization reduces support for public spending because voters do not wish to subsidize those outside of their own group. Alternatively, the median voter theorem, in the context of a uniform tax rate, predicts that as mean income rises relative to median income and lowers the tax price of public spending for the median voter, demand for public spending should rise. Two recent papers investigating the relationship between changes in income inequality at the local level and local school revenue in the U.S. in recent decades both find support for the latter theory dominating empirically (Corcoran and Evans, 2010, henceforth CE; Boustan et al., 2012, henceforth BFWZ).

This finding emphasizes how the relative importance of the two opposing theoretical forces depends on the historical policy context. Goldin and Katz $(1997,2008)$ find that high schools were established earlier-and graduation rates rose earlier-in states with less inequality early in the twentieth century, while CE and BFWZ show greater income inequality within localities was associated with more demand for public spending in the latter part of the century. Measurement and aggregation issues aside, this discrepancy could be resolved if salient major infrastructure investments—-like establishing a public high school—require reaching a higher threshold of political consensus than do incremental increases in revenue used to fund continuous changes in the level of school spending. Notably, CE and BFWZ do not find that inequality is an economically significant explanator of changes in school spending; the increased local revenue they document is 
accompanied by declining state revenue. BFWZ find that declining state revenue more than offset all inequality-induced increases in local revenue in states with court-ordered school finance equalizations, and offset nearly all such increases in states without such reforms.

I next examine correlations between state-level inequality and high school graduation rates from 1963 to 2007. These could operate through any effects on spending, or through other channels. For example, the positive established relationship between income inequality and income segregation combined with the residentially based school attendance policies of most districts could make increases in inequality translate into an increase in school segregation by income, which might independently affect graduation rates conditional on mean state spending levels.

I choose to conduct this exercise at the state rather than local level (as in CE and BFWZ) due to several considerable advantages given my preferred graduation rate measure, the ratio of current graduates to eighth grade enrollment five years earlier. Residential and school mobility will cause measurement error in state estimates of the graduation rate defined in this way only due to mobility across states and the public or private sector, rather than also across districts. The state data also cover more years than district data. Finally, analysis at the state level yields more interpretable results when the median voter in the state, rather than the school district, drives the level of school spending; given the increasing role of the states in school finance over the twentieth century, this advantage is more important for studying recent trends than studying the high school movement.

The state level of analysis also has significant drawbacks: it yields far fewer observations, and masks the considerable within-state heterogeneity in key independent and dependent variables. As CE and BFWZ point out, there is more variation in inequality over time during these years within school districts than within states. ${ }^{13}$ And while the presence or absence of a court-

\footnotetext{
${ }^{13}$ Following Roza (2010), moreover, there is considerable variation in resources allocated to students even within the same schools, so the disaggregation problem is exceedingly difficult to solve given current data reporting systems, regardless of researcher access to data.
} 
ordered school finance equalization is appropriately measured at the state level and may well affect mean educational inputs in a state, its impact within any given district is likely to vary from the state average depending on the extent to which the reform redistributes funds to that specific district-generally, a function of the property wealth per pupil in the district relative to the state average. Reforms that do not change state means could still change inputs in those districts with students disproportionately on the margin of high school.

I use state-year level data to describe correlations between high school graduation rates and income inequality, controlling for basic demographics (percent nonwhite and median family income). I then apply the same framework to examine relationships between inequality and education spending per pupil. For both sets of analyses, I allow court-ordered school finance reforms to exert independent effects on the dependent variable. The analysis is of state-level aggregates of current spending, so it reflects combined revenue decisions at federal, state, and local levels.

The major caveats to this empirical exercise are familiar to readers of education research: first, inputs are endogenous to the preferences of voters in the state and its districts (CE and BFWZ take considerable care with this issue); second, there is variation in inputs at the student level within states, districts, and schools, so the average level of school spending does not necessarily apply to the student on the margin of dropping out; and third, aggregation issues aside, the theoretically relevant inputs (educational quality) and outputs (human capital acquired through formal schooling) to analyze are difficult to quantify. To some extent, I can circumvent the first issue by considering the effects of court-ordered school finance equalizations, though the impact of such measures are mediated by political decisions regarding aggregate levels of resources for elementary and secondary education. 
I define the graduation rate at the state $(s)$ and year $(t)$ level as the count of new graduates (excluding GED recipients) divided by the number of students enrolled in eighth grade five years earlier, as described by equation [1].

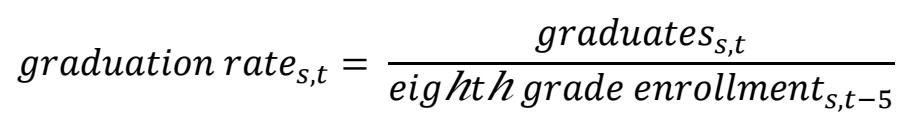

I begin with the general approach of Goldin and Katz's analysis (see their Table 6.1, 2008) to correlate graduation rates, year by year, with baseline (in this case, 1963) state characteristics. Because each regression is estimated using only 48 state-level observations, I limit these characteristics to the inequality measures of interest - the 90/50 and 50/10 family income ratios, represented by INEQ in equation [2] below—and control additionally only for median family income and percent nonwhite, in $X$ below. I use decennial Census data for income and race variables, which I linearly interpolate for intercensal years, and use ACS data for 2007. I calculate these variables for families with school-aged children, as their characteristics will directly affect graduation rates. I also include regional fixed effects. Equation [2] below describes the specification.

$$
y_{s, t}=\propto_{t}+I N E Q_{s} \gamma_{t}+X_{s} \delta_{t}+R E G I O N_{s} \eta_{t}+\varepsilon_{s, t}
$$

Because school quality can affect population characteristics, using fixed measures of inequality and demographics from the baseline period (1963) helps mitigate potential endogeneity. The drawback is that I estimate each year's regression on only 48 observations, and miss the variation in inequality coming from the trends in decades to follow.

Table 1 provides summary statistics of the measures used, in both 1963 and 2007. Over the time period studied, it reveals increases in family income inequality at the top and smaller increases in inequality at the bottom of the distribution, alongside declines in child poverty rates. The nonwhite child population grew as a share of the total, and median real family income rose for families with children. At the start of the period of analysis, in 1963, no states had court-mandated school finance reforms and by the end in 2007 it was the norm. Based on demographics alone, it is 
unclear how we would expect the high school graduation rate to change. The true change in the graduation rate was small and positive, about a 2.2 percentage point increase. School spending (in 2011 dollars) more than tripled.

Table 2 describes the results of the ordinary least squares specification above. In Panel A, the dependent variable $y$ is the graduation rate, and in Panel B, it is current spending per pupil. All regressions control for median family income and percent nonwhite in 1963; the estimated coefficients are not shown but are often significant and in the expected directions. Regional dummy variables are also not shown. Consistent with Figure 2, the South experienced secular gains in graduation rates while the West lost. In later decades, all regions had significantly lower levels of school spending than the Northeast, even after controlling for race and income.

Both the specifications predicting graduation and spending yield generally noisy estimates. Results for 1963, the only year of analysis in which the independent inequality and demographic variables are measured at concurrent rather than pre-existing levels, are marginally statistically significant. Column [1] of Panel A shows that in 1963, the 50/10 ratio was negatively correlated with graduation rates; this is consistent with the considerable literature demonstrating a strong correlation between family socioeconomic characteristics and graduation. Panel B shows a marginally statistically significant positive relationship between the 90/50 ratio and school spending, consistent with a reduction in the median voter's tax price of funding schools.

The only other statistically significant results are from the estimated positive relationship between the initial 90/50 ratio and graduation, in Panel A, in 1990 and 2000. If no other covariates changed over time, applying these coefficients to the observed growth in the 90/50 ratio over the time period alone would predict a greater increase in graduation rates than actually observed. Given the variability of the estimates over time, I do not emphasize this result. One possible mechanism consistent with the timing of these estimates is that the growth of accountability programs at the state level in these decades made spending increases (correlated with income 
inequality at the top) more productive for students at the bottom of the achievement distribution in these years. ${ }^{14}$

I also estimate a version of equation [2] predicting changes in outcomes over the entire 1963 to 2007 period, again with the baseline characteristics as predictors. Column (7) presents those results, which are again extremely imprecise. To interpret the magnitude of the statistically insignificant point estimate, holding median income and percent nonwhite constant, a state in which the $90 / 50$ ratio increased from 1963 to 2007 by the national average (0.49) would experience a 3.7 percentage point increase in graduation rates over the time period, exceeding the mean observed actual increase in graduation over those years. In results not shown, these estimates are essentially unchanged when including an independent variable for whether a school finance reform has been judicially mandated in a state by that year. (That variable itself is positive and statistically significant for 1990.)

I next estimate a variant of this specification, described in equation [3], pooling annual data from 1963 to 2007 (the graduation and school spending data are annual; the inequality data are imputed from the decennial Census data). This specification includes fixed effects for states and years. It differs significantly from the Goldin and Katz approach by including concurrent rather than baseline demographic independent variables: again median family income, percent nonwhite, and the 50/10 and 90/50 family income ratios. These concurrent variables allow investigation of a fuller scope of changes in demographics and income inequality in the latter part of the century.

\footnotetext{
${ }^{14}$ Murnane (2013) suggests that the movement towards standards and accountability and corresponding policies such as high school exit exams might have encouraged those on the margin of dropping out to do so. He also points out, however, that data from the National Assessment of Educational Progress reveal improvements in achievement levels for thirteen year olds near the bottom of the distribution (at the twentyfifth percentile) since 1999, breaking trend from the preceding decade. This improvement could be due in part to standards and accountability programs, and could promote high school graduation. Both mechanisms could be operating, with students responding to the pressure of high school exit exams by dropping out before any positive impacts of accountability programs filtered down to persistence decisions via improved achievement in lower grades.
} 
Because school spending and high school graduation rates can themselves affect income inequality within a state, I emphasize the descriptive nature of these correlations. ${ }^{15}$

$$
y_{s, t}=\propto_{t}+I N E Q_{s, t} \gamma+X_{s, t} \delta+\theta_{s}+\eta_{t}+\varepsilon_{s, t} \quad[3]
$$

The results from this specification are in Table 3. All columns include controls for median family income and percent nonwhite. Column 1 includes only current 90/50 and 50/10 family income ratios as additional independent variables of interest. Unlike baseline income inequality in Table 2, current income inequality—at both the bottom and top of the distribution-appear to be significantly correlated with both graduation and spending. Some estimates change meaningfully as more control variables are added, however. Column 2 adds an indicator variable for whether the state has had a court-ordered school finance equalization (SFE), and Column 3 adds the poverty rate, which eliminates the relationship between inequality at the bottom and graduation rates and reduces the estimated relationship between inequality at the bottom and school spending. This is unsurprising given the multiple potential mechanisms consistent with the positive correlation between inequality at the bottom and spending being driven by poverty rather than inequality per se: poor children are more costly to educate (for example, because of their disproportionate representation in special education programs); spending rises with poverty because of federal Title I funds (see Cascio and Reber, 2012); or school finance reforms or state categorical programs require more funding for poorer districts. Similarly, while inequality at the bottom could reduce graduation rates via a culture of despair type of argument, 16 it could be the correlation with poverty that is responsible, consistent with a large literature on the role of individual socioeconomic characteristics and educational attainment. For these reasons, I focus my discussion

\footnotetext{
15 My method is analogous to the OLS method of BFWZ. They address the endogeneity issues inherent in this approach by also applying national trends in income growth to initial local income distributions, creating instruments for subsequent local inequality levels.

${ }^{16}$ See Kearney and Levine (2012), which shows that conditional on individual poverty status, inequality in a state is positively correlated with teen childbearing, and Kearney and Levine (2013), which shows the same result for high school dropout.
} 
about interpreting the magnitudes of the coefficients to Column 3, with the full set of independent variables. ${ }^{17}$

Applying the coefficients from Column 3 of Table 3 to the change in the (weighted) national average suggests that the benefit of declining poverty (predicted to increase graduation by 3.5 percentage points) was nearly fully offset by the increasing share of nonwhite population (coefficient not shown, predicted to decrease graduation by 3.1 percentage points). The effects of median family income and inequality at the bottom on graduation, with these other controls, were both statistically insignificant (income result not shown in table). The positive 90/50 coefficient, applied to the historical change in that ratio, would imply on its own a 4.3 percentage point increase in graduation rates. In sum, we observe only about a third of the increase in graduation rates in the actual data that a causal interpretation of these correlations would imply.

Panel B of Table 3 considers the relationships of the same set of variables with (real) school spending rather than graduation rates as the dependent variable. These correlations are perhaps more plausible - the full set of covariates explains about half of the sizeable increase in school spending overall spanning these years. Of this half, the rise in median family income predicts about two-thirds and the rise in the $90 / 50$ family income ratio 28 percent. The incidence of the state and local taxes generating these increases varies by time and jurisdiction, so it is not clear that on net this should be viewed as an improvement in progressivity that could be the silver lining in increased income inequality.

In sum, inequality at the top, poverty, and inequality at the bottom all appear to be positively correlated with school spending; inequality at the top is positively correlated with graduation rates, while poverty is negatively so and inequality at the bottom is not significantly correlated with graduation once controlling for poverty. Given that students whose families are at the $90^{\text {th }}$ percentile of income are generally not on the margin of dropping out, it seems plausible

${ }^{17}$ In analyses not shown, specifications including the interactions between SFEs and inequality yield highly imprecise estimates. 
that the positive correlation between inequality at the top and graduation operates through lowering the median voter's tax price and increasing school spending. The negative correlation between poverty and graduation is unsurprising, even given the positive relationship between poverty and spending, given the established strong negative correlation between individuals' own socioeconomic characteristics and graduation. These estimates cannot reveal whether the additional spending induced by higher poverty increases graduation but not enough to offset the negative effects of poverty status on educational attainment, or whether poverty-induced spending - which is more dependent on categorical aid with restrictions on its use-is ineffective (see Junge and Krvaric, 2011). The positive relationship between inequality at the bottom and school spending, conditional on poverty, is somewhat puzzling.

As with Altonji and Mansfield, which one could view as a micro-level analysis of these forces for two different points in time, this analysis is suggestive and does not support causal interpretation. State education policies and inputs likely respond to public opinion about school quality, whether actual or perceived. The income distribution in a state is determined in part by graduation rates in the state in earlier years, which could affect fertility, cross-state migration, and earnings of residents born and educated in the state.

\section{Additional determinants of graduation rates excluded from this analysis}

This limited exercise neglects to empirically examine the role of several key factors potentially changing over the time period and shown by other research to affect the acquisition of human capital. The following discussion of such omitted forces is by no means complete, and is simply meant to touch on some of the most major forces. Perhaps most critically, research in the social and life sciences increasingly recognizes the importance of early life environment and experiences in shaping human capital, including cognitive and non-cognitive skills as well as health outcomes. The now well-established fact that gaps in cognitive ability by socioeconomic status are present by the time children enter kindergarten (Duncan and Magnuson, 2011) confirms that 
attempting to analyze variation in high school graduation solely as a factor of elementary and secondary education policies is necessarily limited, and suggests the potential for many policies to ultimately affect educational attainment. These could include policies affecting maternal exposure to a variety of environmental toxins and licit and illicit drugs (Currie, 2011), pre- and post-natal nutrition (Almond, Hoynes, and Schanzenbach, 2011), and the quality of childcare environments prior to enrollment in elementary school, including the home environment (Phillips, 2011). Most dramatically, recent work by Figlio et al. (2013) shows that the negative effect of low birth weight on academic test scores through third grade is insensitive to school quality.

\section{CONCLUSION}

The descriptive results presented raise an interesting question. If, as these results suggest (but counter to the magnitudes estimated by CE and BFWZ), the growth in income inequality in recent decades led to increased school spending, would a better-identified setting (e.g., one with exogeneous changes in inequality) show a positive relationship between inequality and student outcomes? If so, would the benefits of inequality-induced additional resources reach students throughout the achievement distribution? There could be a positive impact of these funds on graduation rates, but one that is more than offset by other mechanisms through which inequality negatively affects attainment. Alternatively, little to none of the increases in spending at the district level may be making their way to productive investments in those students on the margin of dropping out of high school. This could be due to the non-uniform allocation of resources across schools within districts or within individual schools, or if the restrictions placed on categorical funds inhibit their utility.

Research on school quality has been moving towards the more productive exercise of assessing returns to specific inputs, as opposed to dollars spent per pupil. As researchers have shown convincing correlations between specific inputs and educational outcomes, public policy has 
begun to embrace these findings. For example, consider the extent to which Race to the Top rewards the use of specific technologies in educational production, including those enabling the identification of teacher-specific contributions to achievement-a decade ago, or even less, this policy would seem politically impossible. Yet the role for research to inform policy is still limited as the most compelling input to school quality identified to date-teacher quality—has been identified essentially as a residual and it is not clear how policies can manipulate its level or distribution. Research into the production, rather than identification, of teacher quality is an important next frontier for this literature. As recent efforts of the National Council on Teacher Quality reveal, this is a politically fraught endeavor, facing major resistance from schools of education and teachers' unions.

Another fruitful avenue for future research on education production functions is to consider the regulatory environments in which resources are allocated, at the state, district, and school levels. Regulation of federal Title I funds increased-both in terms of formal requirements and actual enforcement-in response to early reports of malfeasance (see Martin and McClure, 1969), and other categorical programs, from federal and state sources, have followed suit with their own requirements. The initial push for greater regulation came about in response to a large volume of reports of school districts using federal funds to maintain a desired unequal distribution of total resources. The regulatory environment today has evolved such that critics fear it poses serious difficulties for districts genuinely attempting to equalize the quality of education across their schools (for detailed descriptions of particular regulations, see Junge and Krvaric, 2011; for discussion of the opaque and non-uniform allocation of resources within districts, see Roza, 2010). This allocation poses difficulties for researchers as well, who regularly implicitly view reported revenues and expenditures at the school district level as predictive of student-level resources throughout the district. 
The world of quantitative research in education has changed dramatically in the last decade. No Child Left Behind brought with it a push for "scientifically-based research" emphasizing exogenous variation in educational inputs and large, quantitative datasets. Ideally this new orientation can be merged productively with careful attention to institutional detail, allowing for the creation of accessible data on the most relevant variables, to produce the research necessary to guide investments in future generations of human capital. 


\section{References}

Alesina, Alberto, Reza Baqir, and William Easterly. 1999. "Public Goods and Ethnic Divisions." Quarterly Journal of Economics 114(4), 1243-1284.

Almond, Douglas, Hilary Hoynes, and Diane Schanzenbach. "Inside the War on Poverty: The Effect of the Food Stamp Program on Birth Outcomes." Review of Economics and Statistics 93(2), 387-403.

Altonji, Joseph G. and Richard K. Mansfield. 2011. "The Role of Family, School, and Community Characteristics in Inequality in Education and Labor-Market Outcomes." In Greg J. Duncan and Richard J. Murnane, eds., Whither Opportunity? Rising Inequality, Schools, and Children's Life Chances. New York: Russell Sage Foundation.

Autor, David H., Lawrence F. Katz, and Melissa S. Kearney. 2008. "Trends in U.S. Wage Inequality: Revising the Revisionists." Review of Economics and Statistics 90(2), 300-323.

Bacolod, Marigee. 2007. "Do Alternative Opportunities Matter? The Role of Female Labor Markets in the Decline of Teacher Quality, 1960-1990." Review of Economics and Statistics, 89(4), 737-751.

Balfanz, Robert and Nettie Legters. 2004. "Locating the Dropout Crisis." Center for Research on Education of Students Placed At Risk, Report 70.

Becker, Gary S. 1994. Human Capital: a Theoretical and Empirical Analysis, with Special Reference to Education. Vol. no.80. New York: National Bureau of Economic Research; distributed by Columbia University Press.

Boustan, Leah, Fernando Ferreira, Hernan Winkler, and Eric Zolt. 2012. "The Effect of Rising Income Inequality on Taxation and Public Expenditures: Evidence from US Municipalities and School Districts, 1970-2000." Forthcoming, Review of Economics and Statistics.

Briffault, Richard. 2005. "The Local School District in American Law." In William G. Howell, ed., Besieged: School Boards and the Future of American Politics. Washington, DC: Brookings, 2455.

Burch, Patricia. 2006. "The New Educational Privatization: Educational Contracting and High Stakes accountability." Teachers College Record 108(12), 2582-2610.

Card, David, and A. Abigail Payne. 2002. "School finance reform, the distribution of school spending, and the distribution of SAT scores," Journal of Public Economics, 83(1), 49-82.

Cascio, Elizabeth, and Sarah Reber. 2012. “The War on Poverty's K-12 Education Battle: The History and Legacy of Title I." In Bailey and Danziger, eds. The Legacies of the War on Poverty (volume under review).

Cascio, Elizabeth, Nora Gordon, Ethan Lewis, and Sarah Reber. 2008. "From Brown to Busing." Journal of Urban Economics 64(2), 296-325. 
Cascio, Elizabeth, Nora Gordon, Ethan Lewis, and Sarah Reber. 2010. "Paying for Progress: Conditional Grants and the Desegregation of Southern Public Schools." Quarterly Journal of Economics 125(1), 445-482.

Cascio, Elizabeth, Nora Gordon, and Sarah Reber. 2013. "Local Responses to Federal Grants: Evidence from the Introduction of Title I in the South." Forthcoming, American Economic Journal: Economic Policy.

Chetty, Raj, John N. Friedman, and Jonah H. Rockoff. 2011. “The Long-Term Impacts of Teachers: Teacher Value-Added and Student Outcomes in Adulthood." Cambridge, MA: National Bureau of Economic Research working paper no. 17699.

Chetty, Raj, John N. Friedman, Nathaniel Hilger, Emmanuel Saez, Diane Schanzenbach, and Danny Yagan. 2011. "How does Your Kindergarten Classroom Affect Your Earnings? Evidence from Project STAR." Quarterly Journal of Economics 126 (4), 1593-1660.

Cohen, David K. and Susan L. Moffitt. 2009. The Ordeal of Equality: Did Federal Regulation Fix the Schools? Cambridge, Mass.: Harvard University Press.

Coleman, James S., Ernest Q. Campbell, Carl F. Hobson, James McPartland, Alexander M. Mood, et al. 1966. Equality of Educational Opportunity. Washington: U. S. Office of Education.

Corcoran, Sean and William N. Evans. 2010. "Income inequality, the median voter, and the support for public education." Cambridge, MA: National Bureau of Economic Research working paper no. 16097.

Corcoran, Sean P. and William N. Evans. 2008. "Equity, Adequacy and the Evolving State Role in Education Finance," in Handbook of Research in Education Finance and Policy, Helen F. Ladd and Edward B. Fiske, eds. New York: Routledge, 332-356.

Corcoran, Sean P., William N. Evans, and Robert M. Schwab. 2004. "Changing Labor Market Opportunities for Women and the Quality of Teachers, 1957-2000," In American Economic Review, Papers and Proceedings of the American Economic Association 94(2), 230-235.

Currie, Janet. 2011. "Inequality at Birth: Some Causes and Consequences.” American Economic Review 101(3), 1-22.

Dee, Thomas and Brian Jacob. 2011. "The Impact of the No Child Left Behind Act on Student Achievement." Journal of Policy Analysis and Management 30(3), 418-446.

Duncan and Magnuson. 2011. "The Role of Family, School, and Community Characteristics in Inequality in Education and Labor-Market Outcomes." In Greg J. Duncan and Richard J. Murnane, eds., Whither Opportunity? Rising Inequality, Schools, and Children's Life Chances. New York: Russell Sage Foundation.

Duncan, Greg J., and Richard J. Murnane. 2011. "Introduction: The American Dream, Then and Now.” In Greg J. Duncan and Richard J. Murnane, eds., Whither Opportunity? Rising Inequality, Schools, and Children's Life Chances. New York: Russell Sage Foundation. 
Evans, William, Craig Garthwaite and Timothy J. Moore. 2012. "The White/Black Educational Gap, Stalled Progress, and the Long-term Consequences of the Emergence of Crack Cocaine Markets." Cambridge, MA: National Bureau of Economic Research working paper no. 18437.

Ferguson, Ronald. 2008. "What We've Learned about Stalled Progress in Closing the Black-White Achievement Gap." Steady Gains and Stalled Progress: Inequality and the Black-White Test Score Gap, K. Magnuson and J. Waldfogel, eds. Russell Sage Foundation Press: New York.

Figlio, David N., Jonathan Guryan, Krzysztof Karbownik, and Jeffrey Roth. 2013. "The Effects of Poor Neonatal Health on Children's Cognitive Development." Cambridge, MA: National Bureau of Economic Research working paper no. 18846.

Fischel, William. 1989. “Did Serrano Cause Proposition 13?” National Tax Journal 42, 465-474.

Forbes, Silke and Nora Gordon. 2012. "When Educators Are the Learners: Private Contracting by Public Schools." The B.E. Journal of Economic Analysis \& Policy, Berkeley Electronic Press, vol. 12(1), 31.

Freeman, Richard B. 1976. The Overeducated American. New York: Academic Press.

Goldin, Claudia, and Lawrence F. Katz. 1997. "Why the United States Led in Education: Lessons from Secondary School Expansion, 1910 to 1940." Cambridge, MA: National Bureau of Economic Research working paper no. 6144.

Goldin, Claudia and Lawrence F. Katz. 2008. The Race Between Education and Technology. Cambridge, Mass.: Harvard University Press.

Gordon, Nora. 2004. “Do Federal Grants Boost School Spending? Evidence from Title I," Journal of Public Economics 88(9-10), 1771-1792.

Gordon, Nora. 2008. "The Changing Federal Role in Education Finance and Governance," in Handbook of Research in Education Finance and Policy, Helen F. Ladd and Edward B. Fiske, eds. New York: Routledge, 295-313.

Guin, Kacey, Betheny Gross, Scott Deburgomaster and Marguerite Roza. 2007. "Do Districts Fund Schools Fairly?" Education Next 7(4), 68-73.

Guryan, Jonathan. 2004. "Desegregation and Black Dropout Rates." American Economic Review 94(4), 919-943.

Hanushek, Eric A. 1997. "Assessing the Effects of School Resources on Student Performance: An Update." Educational Evaluation and Policy Analysis 19(2), 141-164.

Heckman, James J., and Paul A. LaFontaine. 2010. "The American High School Graduation Rate: Trends and Levels." Review of Economics and Statistics 92(2), 244-262.

Heckman, James J., John Eric Humphries, Paul A. LaFontaine, and Pedro L. Rodriguez. 2012. "Taking the Easy Way Out: How the GED Testing Program Induces Students to Drop Out." Journal of Labor Economics 30(3), 495-520. 
Heuer, Ruth and Stephanie Stullich. 2011. "Comparability of State and Local Expenditures among Schools within Districts: A Report from the Study of School-Level Expenditures." Office of Planning, Evaluation and Policy Development, US Department of Education.

Hoxby, Caroline M. 2001. "All School Finance Equalizations Are Not Created Equal." Quarterly Journal of Economics 116(4).

Hoxby, Caroline, M. and Andrew Leigh. 2004. "Pulled Away or Pushed Out? Explaining the Decline of Teacher Aptitude in the United States." American Economic Review 94(2), 236-240.

Junge, Melissa and Sheara Krvaric. 2011. "Federal Compliance Works against Education Policy Goals." Education Outlook 6, American Enterprise Institute.

Kearney, Melissa S. and Philip B. Levine. 2012. "Why Are Teen Birth Rates So High in the U.S. and Why Does It Matter?” Journal of Economic Perspectives 26(2), 141-63.

Kearney, Melissa S. and Philip B. Levine. 2013. "Income Inequality and the Decision to Drop Out of High School.” University of Maryland mimeo.

Krueger, Alan. 1998. "Reassessing the View that American Schools are Broken," Economic Policy Review 4(1), Federal Reserve Bank of New York, 29-46.

Luttmer, Erzo. 2001. "Group Loyalty and the Taste for Redistribution." Journal of Political Economy 109(3), 500-528.

Martin, Ruby and Phyllis McClure. 1969. Title I of ESEA: Is it Helping Poor Children? Washington, DC.: National Association for the Advancement of Colored People and Washington Research Project.

McLanahan, Sara, and Gary D. Sandefur. 1994. Growing Up with a Single Parent: What Hurts, What Helps. Cambridge, MA: Harvard University Press.

McLaughlin, Milbrey. 1976. “Implementation of ESEA Title I: A Problem of Compliance.” Teachers College Record 77(3), 397-415.

Mishel, Lawrence and Joydeep Roy. 2006. Rethinking High School Graduation Rates and Trends. Washington, DC: Employment Policy Institute.

Murnane, Richard. 2013. "U.S. High School Graduation Rates: Patterns and Explanations." Cambridge, MA: National Bureau of Economic Research working paper 18701.

Murray, Sheila E., William N. Evans and Robert M. Schwab. 1998. "'Education-Finance Reform and the Distribution of Education Resources." American Economic Review 88, 789-812.

Neal, Derek. 2006. “Why Has Black-White Skill Convergence Stopped?” In Handbook of the Economics of Education, Eric Hanushek and Finis Welch, eds. Elsevier, 511-576.

Phillips, Meredith. 2011. "Parenting, Time Use, and Disparities in Academic Outcomes." In Whither Opportunity? Rising Inequality, Schools, and Children's Life Chances, Greg J. Duncan and Richard J. Murnane, eds. New York: Russell Sage Foundation. 
Poterba, James. 1997. "Demographic Structure and the Political Economy of Education.” Journal of Policy Analysis and Management 16, 48-66.

Reardon, Sean. 2011. "The Widening Academic Achievement Gap between Rich and Poor: New Evidence and Possible Explanations." In Whither Opportunity? Rising Inequality, Schools, and Children's Life Chances, Greg J. Duncan and Richard J. Murnane, eds. New York: Russell Sage Foundation.

Reber, Sarah. 2010. "Desegregation and Educational Attainment for Blacks," Journal of Human Resources, 893-914.

Rockoff, Jonah. 2004. "The Impact of Individual Teachers on Student Achievement: Evidence from Panel Data," American Economic Review 94(2), 247-252.

Roza, Marguerite. 2010. Educational Economics: Where Do School Funds Go? Urban Institute Press.

Roza, Marguerite, Kacey Guin, and Tricia Davis. 2008. "What Is the Sum of the Parts? How Federal, State, and District Funding Streams Confound Efforts to Address Different Student Types." Seattle, WA: Center on Reinventing Public Education, University of Washington.

Ruggles, Steven, J. Trent Alexander, Katie Genadek, Ronald Goeken, Matthew B. Schroeder, and Matthew Sobek. 2010. Integrated Public Use Microdata Series: Version 5.0 [Machinereadable database]. Minneapolis: University of Minnesota.

Rumberger, Russell W. 2011. Dropping Out: Why Students Drop Out of High School and What Can Be Done about It. Cambridge, Mass.: Harvard University Press.

Swanson, Christopher B. 2004. "High School Graduation, Completion, and Dropout (GCD) Indicators A Primer and Catalog." Washington, DC: Urban Institute.

Vigdor, Jacob L. and Jens O. Ludwig. 2008. "Segregation and the Black-White Test Score Gap." Steady Gains and Stalled Progress: Inequality and the Black-White Test Score Gap, K. Magnuson and J. Waldfogel, eds. Russell Sage Foundation Press: New York.

Watson, Tara, 2009. "Inequality and the Measurement of Residential Segregation by Income." Review of Income and Wealth 55, 820-844. 
Figure 1. U.S. High School Graduation Rates, 1890-2004

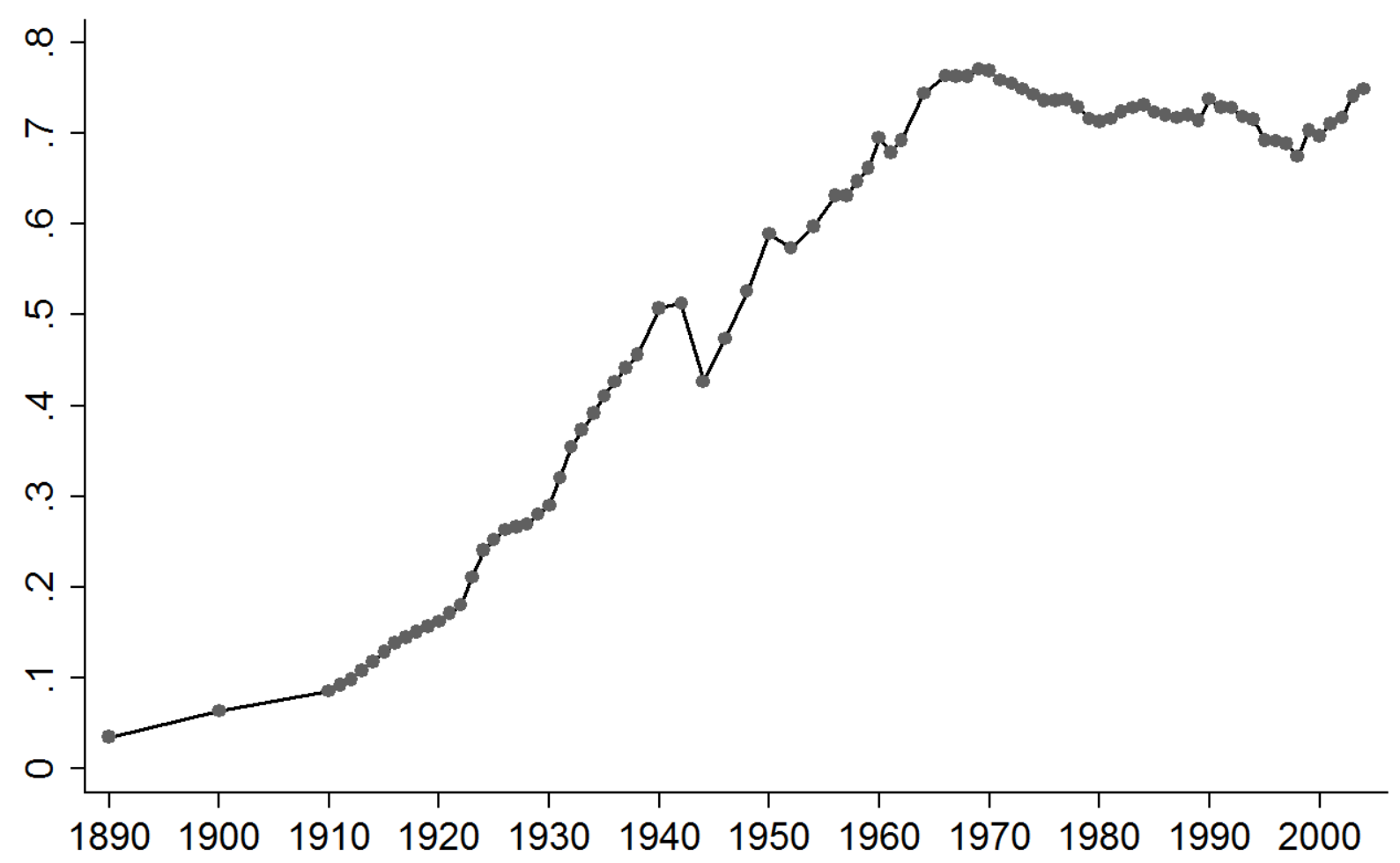

Source: Goldin and Katz (2008), Figure 9.2. 


\section{Figure 2. High School Graduation Rates by Region}

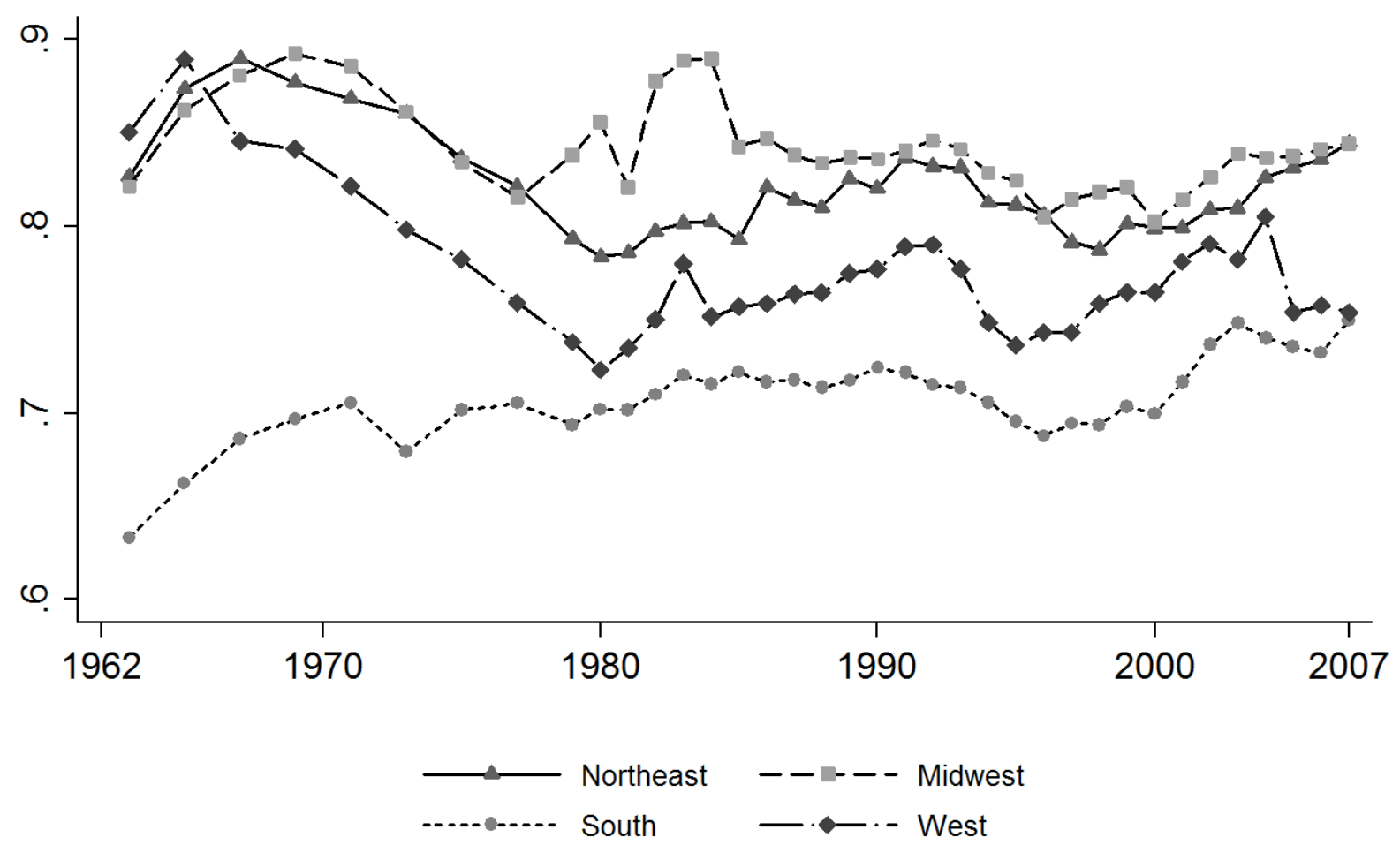

Notes: Graduation rates are calculated as the count of graduates (excluding GEDs where possible) divided by eighth grade enrollment five years previously. Graduate and enrollment by grade data are from state educational agencies (as reported in Statistics of State School Systems and Digests of Education, various years). 
Figure 3. Trends in Spending Per Pupil and the Share of Education Revenue from Local, State and Federal Sources, 1919-2008

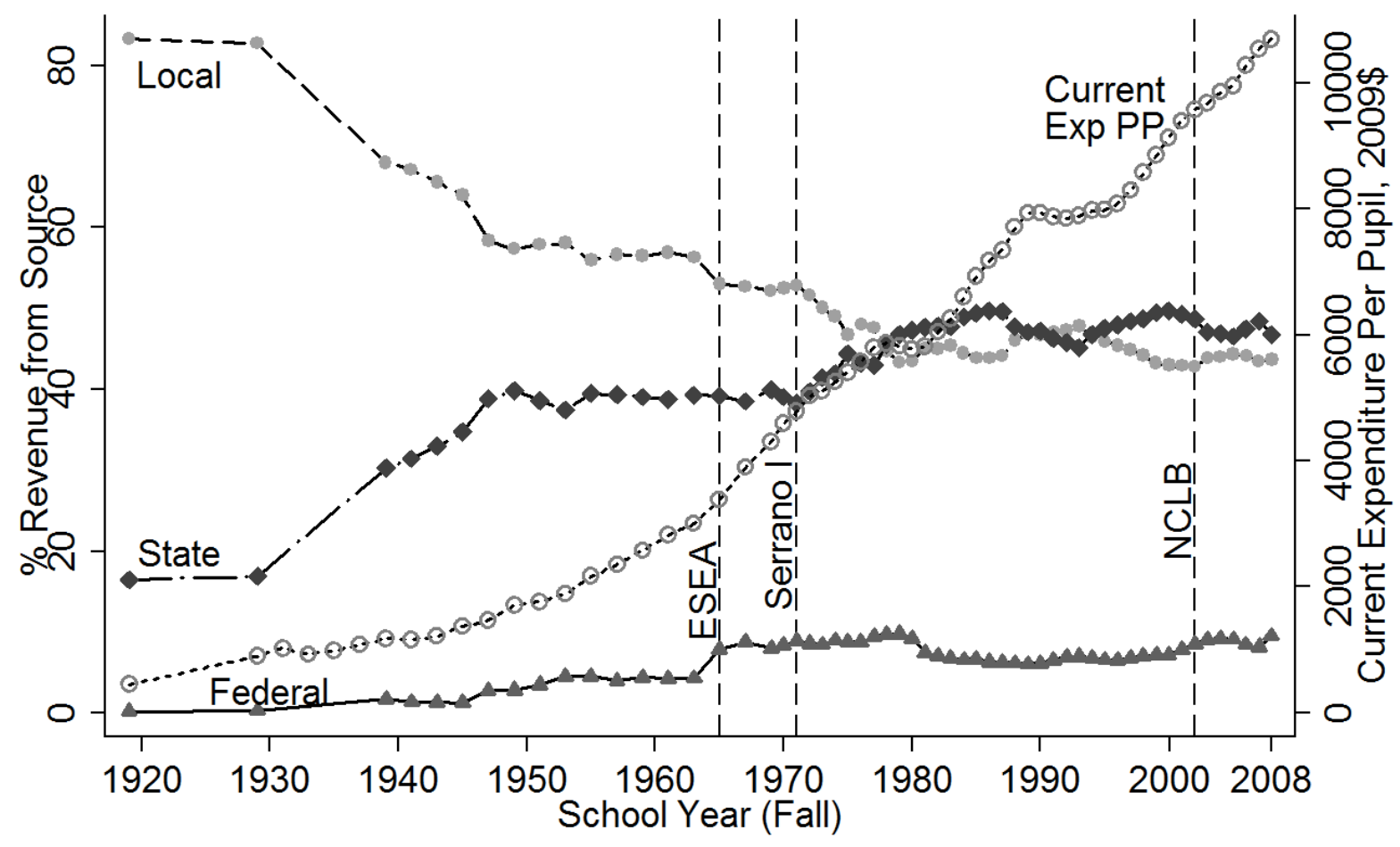

Notes: Spending and revenue data from NCES Digests of Education, various years. 
Figure 4

Allocation of revenue, by source, across schools within anonymous Texas district

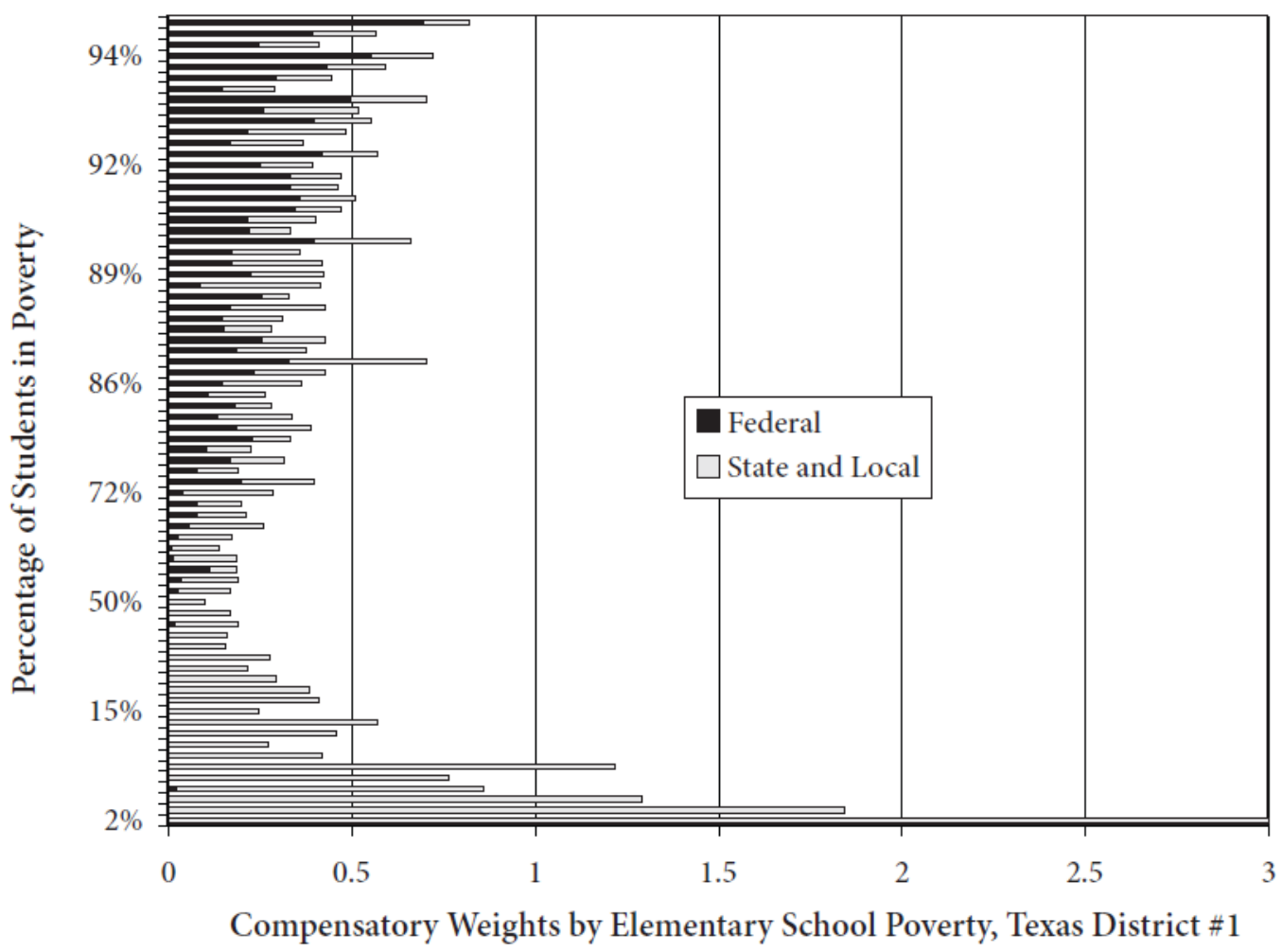

Source: CRPE School Finance Redesign Project. Roza, Guin and Davis, 2008. Data are from 2003-04 school year. 
Table 1. Descriptive Statistics.

\begin{tabular}{|c|c|c|c|c|}
\hline & \multicolumn{4}{|c|}{ Panel A. Weighted by School-aged Population. } \\
\hline & \multicolumn{2}{|c|}{1963} & \multicolumn{2}{|c|}{2007} \\
\hline & mean & s.d. & mean & s.d. \\
\hline High school graduation rate & 0.767 & 0.115 & 0.789 & 0.070 \\
\hline Current spending per pupil (thousands of $2011 \$$ ) & 3.416 & 0.855 & 12.009 & 3.044 \\
\hline $90 / 50$ family income ratio & 1.979 & 0.168 & 2.551 & 0.234 \\
\hline $50 / 10$ family income ratio & 2.989 & 0.83 & 4.074 & 0.454 \\
\hline Median family income & 45,881 & 8,314 & 59,957 & 9,063 \\
\hline Percent school-aged children nonwhite & 13.69 & 11.32 & 30.08 & 10.52 \\
\hline Percent school-aged children in poverty & 22.81 & 11.72 & 16.88 & 3.57 \\
\hline
\end{tabular}

\begin{tabular}{|c|c|c|c|c|}
\hline & \multicolumn{4}{|c|}{ Panel B. Unweighted. } \\
\hline & \multicolumn{2}{|c|}{1963} & \multicolumn{2}{|c|}{2007} \\
\hline & mean & s.d. & mean & s.d. \\
\hline High school graduation rate & 0.740 & 0.107 & 0.789 & 0.082 \\
\hline Current spending per pupil (thousands of $2011 \$$ ) & 3.208 & 0.704 & 11.938 & 2.800 \\
\hline $90 / 50$ family income ratio & 1.989 & 0.184 & 2.476 & 0.481 \\
\hline $50 / 10$ family income ratio & 3.067 & 0.879 & 4.000 & 0.791 \\
\hline Median family income & 44,586 & 8,454 & 59,988 & 10,603 \\
\hline Percent school-aged children nonwhite & 14.57 & 16.8 & 27.26 & 15.66 \\
\hline Percent school-aged children in poverty & 24.47 & 11.76 & 16.11 & 4.55 \\
\hline
\end{tabular}

Notes: Income, poverty, and race data are from decennial Censuses (Ruggles et al.), linearly interpolated between years. School finance equalizations (SFEs) are from Corcoran and Evans (2008). Graduation rates are calculated as the count of graduates (excluding GEDs where possible) divided by eighth grade enrollment five years previously. Spending, graduate and enrollment by grade data are from state educational agencies (as reported in Statistics of State School Systems and Digests of Education, various years). 
Table 2. Relationship between Statewide Income Inequality in 1963 and Subsequent Education Indicators.

Panel A. Dependent Variable: High School Graduation Rate.

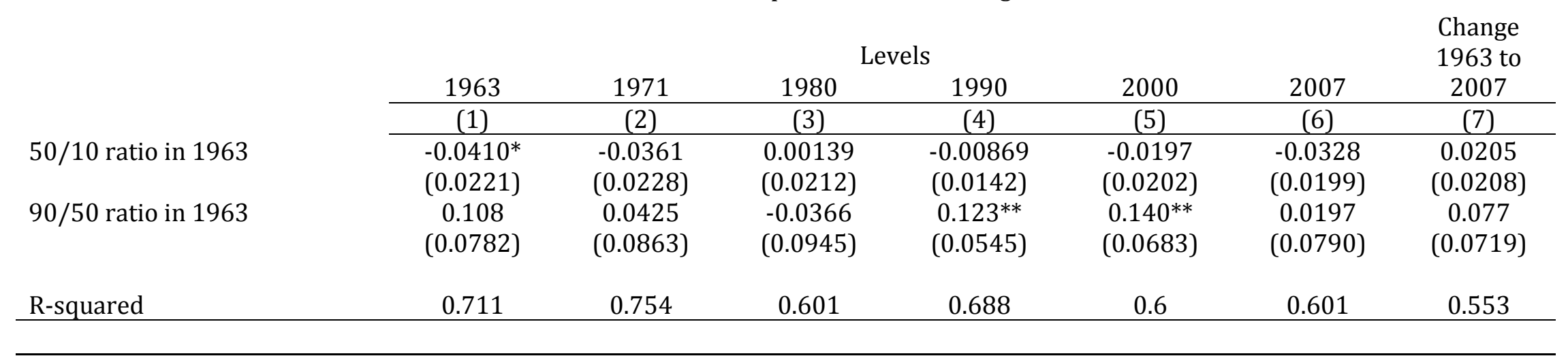

Panel B. Dependent Variable: Current Elementary and Secondary Spending per Pupil

(in 1000s of 2011\$).

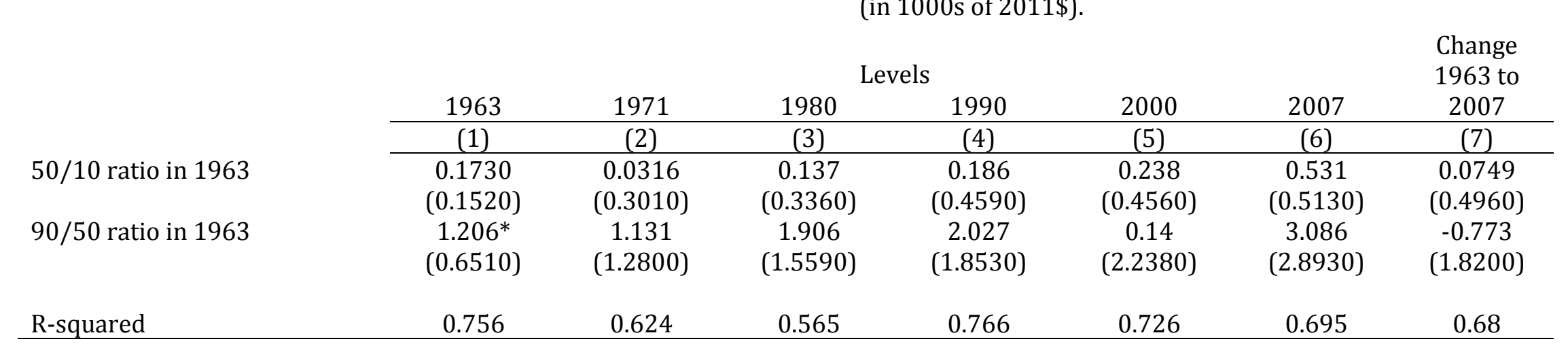

Notes: All regressions include dummy variables for Midwest, South, and West regions and control for initial (1963) median family income and percent nonwhite. Each regression is estimated with 48 observations (the lower 48 states). Income and race data are from decennial Censuses (Ruggles et al., 2010), linearly interpolated between years. Graduation rates are calculated as the count of graduates (in most states excluding GED recipients) divided by eighth grade enrollment five years previously. Spending, graduate and enrollment by grade data are from state educational agencies (as reported in Statistics of State School Systems and Digests of Education, various years). 
Table 3. Relationship between Current Statewide Income Inequality and Education Indicators.

\begin{tabular}{lccc}
\hline \hline & \multicolumn{3}{c}{ Panel A. Dependent Variable: High School Graduation Rate. } \\
& $(1)$ & $(2)$ & $(3)$ \\
\cline { 2 - 4 } $50 / 10$ ratio & $-0.0167^{* * *}$ & $-0.0173^{* * *}$ & 0.0058 \\
& $(0.0039)$ & $(0.0039)$ & $(0.0040)$ \\
90/50 ratio & $0.0973^{* * *}$ & $0.0970^{* * *}$ & $0.0751^{* * *}$ \\
& $(0.0193)$ & $(0.0191)$ & $(0.0181)$ \\
SFE & & $0.0142^{* * *}$ & $0.0184^{* * *}$ \\
& & $(0.0035)$ & $(0.0033)$ \\
\%poor & & & $-0.0058^{* * *}$ \\
& & & $0.0005)$ \\
R-squared & 0.822 & 0.824 & 0.835 \\
\hline
\end{tabular}

Panel B. Dependent Variable: Current Elementary and Secondary Spending per Pupil (in 1000s of 2011\$).

(1)

$50 / 10$ ratio

$90 / 50$ ratio

SFE

\%poor
$0.9449 * * *$

$(0.0790)$

$2.4833^{* * *}$

(0.3647)

R-squared
(2)

$\begin{array}{ll}0.9027^{* * *} & 0.6227^{* * *} \\ (0.0787) & (0.1197)\end{array}$

$(0.0787)$

$2.0885^{* * *}$

(0.3487)

$0.4652^{* * *}$

(0.0775)

$0.4558^{* * *}$

$(0.0770)$

$0.0558^{* * *}$

$(0.0150)$

Notes: All regressions include state and year dummy variables. Income, poverty, and race data are from decennial Censuses (Ruggles et al., 2010), linearly interpolated between years. School finance equalizations (SFEs) are from Corcoran and Evans (2008). Graduation rates are calculated as the count of graduates (excluding GEDs where possible) divided by eighth grade enrollment five years previously. Spending, graduate and enrollment by grade data are from state educational agencies (as reported in Statistics of State School Systems and Digests of Education, various years). 